\title{
KEMAMPUAN PENGELOLAAN KELAS GURU TERHADAP PROSES PEMBELAJARAN DI SDN 02 BANJARAN JEPARA
}

\author{
Aan Widiyono ${ }^{1}$, Syailin Nichla Choirin Attalina ${ }^{2}$, Wulan Sutriyani ${ }^{3}$ \\ ${ }^{123}$ Program Studi PGSD Universitas Islam Nahdlatul Ulama Jepara
}

Email: aan.widiyono@unisnu.ac.id, syailin@unisnu.ac.id, sutriyani.wulan@unisnu.ac.id

\begin{abstract}
This research aims to describe the various ways teachers use to manage the class well. This study uses qualitative approach with the subjects of 7 teachers, 21 students, and principals. Data collection techniques used are observations, interviews, and documentation. Analyze data using models interactive miles and huberman. Test the validity of data using source triangulation and techniques. The results showed that the management of main teacher at SDN 02 Banjaran Jepara goes well, as in the application of class management principles including warm and enthusiastic, challenges, variety, flexibility, emphasis on positive aspects and the cultivation of self-discipline. While at the stage of designing the physical environment teachers have different teaching styles in each class, and teachers have been able to create a positive climate in effective learning.
\end{abstract}

\section{Keywords: Classroom management, Teacher Skills, Learning Process}

\begin{abstract}
Abstrak. Penelitian ini bertujuan untuk mendeskripsikan berbagai cara yang dilakukan guru untuk mengelola kelas dengan baik. Penelitian ini menggunakan pendekatan kualitatif dengan subjek penelitian 7 guru, 21 siswa, dan kepala sekolah. Teknik pengumpulan data menggunakan observasi, wawancara, dan dokumentasi. Analisis data menggunakan model interaktif Miles dan Huberman. Uji keabsahan data menggunakan triangulasi sumber dan teknik. Hasil penelitian menunjukkan bahwa pengelolaan kelas guru di SDN 02 Banjaran Jepara berjalan dengan baik, seperti dalam penerapan prinsip-prinsip manajemen kelas diantaranya hangat dan antusias, tantangan, bervariasi, keluwesan, penekanan pada hal-hal yang positif, dan penanaman disiplin diri. Sedangkan pada tahap merancang lingkungan fisik kelas, guru memiliki gaya mengajar berbeda di tiap kelas, dan guru sudah mampu menciptakan iklim positif dalam pembelajaran yang efektif.
\end{abstract}

Kata Kunci: Pengelolaan kelas, Guru, Proses Pembelajaran

\section{PENDAHULUAN}

Belajar merupakan proses yang komplek dan terjadi pada setiap orang sepanjang hidupnya. Proses belajar itu terjadi karena interaksi antara seseorang dan lingkungannya, sehingga dalam proses belajar dapat terjadi kapan dan dimana saja. Proses pembelajaran dan kegiatan pengelolaan kelas adalah dua hal yang saling berkaitan, namun keterkaitan pengelolaan kelas tersebut memiliki perbedaan karena keduanya memiliki tujuan yang berbeda. Djamarah (2006: 27) mengatakan bahwa pengelolaan kelas 
merupakan suatu upaya memperdayakan potensi kelas yang ada seoptimal mungkin untuk mendukung proses pembelajaran.

Upaya untuk mengoptimalkan kegiatan pembelajaran yang efektif membutuhkan keterlibatan dan peran guru di ruang kelas. Guru diharapkan dapat menciptakan suasana kondusif dalam proses belajar dan memungkinkan peserta didik dapat berekspresi dengan bebas, menyenangkan, dan penuh semangat dalam belajar untuk mempelajari dan memahami esensi berbagai hal yang mereka pelajari.

Dengan ini, proses belajar mengajar yang diselenggarakan di beberapa sekolah dimaksudkan dapat memberikan perubahan pada diri sendiri secara terencana baik dari segi kognitif, afektif dan psikomotorik. Wibowo (2013: 116) menjelaskan bahwa interaksi belajar dapat dipengaruhi oleh beberapa komponen yaitu: murid, guru, kepala sekolah, materi pelajaran, sarana prasarana (perpustakaan), lingkungan dan beberapa fasilitas lain yang memenuhi proses pembelajaran.

Danim (2010: 166) menyatakan bahwa pengelolaan kelas (classroom management) yaitu pengelolaan (manajemen) dan kelas dalam makna ruang kelas (classroom). Manajemen atau pengelolaan merupakan proses penggunaan sumber daya secara efektif untuk mencapai sasaran, sedangkan kelas diartikan secara umum sebagai sekelompok siswa yang ada pada watu yang sama menerima pelajaran yang sama dari guru yang sama pula. Dalam pengelolaan kelas, guru memiliki peranan yang sangat penting dalam pendidikan. Baik buruknya suatu pendidikan dipengaruhi oleh bagaimana seorang guru dapat menyampaikan materi pembelajaran dan mengelola suatu kelas dengan baik.

Dengan pengelolaan manajemen kelas yang baik, siswa diharapkan dapat termotivasi dalam mengikuti pembelajaran, yang terpenting dalam suatu manajemen kelas. Suasana kelas yang menarik dan kondusif merupakan modal penting bagi jernihnya pikiran dalam mengikuti pelajaran, sehingga anak akan merasa nyaman dan antusias. Dengan pembelajaran yang kondusif dan suasana yang cenderung rekreatif, maka akan dapat mendorong siswa untuk mengembangkan potensi kreatifitasnya.

Selain itu, guru dengan segala kompetensinya juga dituntut untuk mempertahankan keadaan yang positif dalam belajar, sekaligus dituntut untuk mengubah keadaan yang negatif dalam belajar di kelas. Itulah sebabnya seorang guru harus mengetahui cara manjemen kelas yang baik untuk modal awal yang harus dimiliki sebagai seorang manajer kelas. Mudasir (2011: 8) mengatakan bahwa keterampilan yang harus dimilki oleh guru dalam memanajemen kelas yaitu: 1) Menata tempat duduk siswa, 2) Menata alat peraga yang ada didalam kelas, 3) Menata kedisiplinan siswa, 4) Menata pergaulan siswa, 5) Menata tugas siswa, 6) Menata ruang fisik, 7) Menata kebersihan dan keindahan kelas, 8) Menata kelengkapan kelas, 9) Menata pajangan siswa.

Tanpa pengelolaan kelas yang efektif, maka proses belajar-mengajar akan terganggu. Jadi, pengelolaan kelas yang efektif merupakan syarat utama agar proses belajar-mengajar menjadi lebih kondusif. Dari hal tersebut, Tujuan umum 
penelitian ini adalah untuk memecahkan masalah yang berkaitan dengan motivasi belajar peserta didik dengan pengelolaan manajemen kelas yang baik.

Terry dalam Danim (2010: 98) menyatakan bahwa Pengelolaan manajemen kelas adalah proses perencanaan, pengorganisasian, aktuasi, dan pengawasan yang dilakukan oleh guru, baik individual maupun dengan atau melalui orang lain (teman sejawat atau siswa sendiri) untuk mencapai tujuan pembelajaran yang efektif dan efisien dengan cara memanfaatkan segala sumber daya yang ada. Seorang guru yang baik sudah sepantasnya dapat mengelola kelas dan juga mengelola pembelajaran dengan baik (Syamsuwir, S., 2019). Dalam menerapkan pengelolaan manajemen kelas tentunya guru harus mampu memahami kondisi siswa dan lingkungan belajar. Hal ini sejalan dengan penelitian yang dilakukan oleh Puspita (2017) yang menyatakan bahwa dalam menerapkan pengelolaan manajemen kelas ada beberapa faktor yaitu penerapan prinsipprinsip pengelolaan kelas, merancang lingkungan fisik kelas, menciptakan iklim belajar yang efektif, menjadi komunikator yang baik.

Berdasarkan hal tersebut peneliti tertarik untuk mengangkat judul "Kemampuan Pengelolaan Kelas Guru terhadap Proses Pembelajaran di SDN 02 Banjaran Jepara".

\section{METODE}

Penelitian ini menggunakan pendekatan kualitatif dengan metode deskriptif. Peneliti menggunakan teknik purposive sampling yang diambil untuk mendapatkan informasi yang dibutuhkan.
Pada penelitian ini, peneliti mengambil subjek utama penelitian, yaitu guru kelas I-VI serta subjek pendukung, yakni siswa dan kepala sekolah.

Teknik pengumpulan data pada penelitian ini, yaitu observasi, wawancara, dokumentasi. Observasi yang digunakan peneliti, yaitu observasi nonpartisipatif, jenis wawancara semiterstruktur, dan dokumentasi berupa foto kondisi kelas dan tata tertib.

Penelitian ini mengunakan 2 jenis sumber data, yaitu sumber data primer dan sumber data sekunder. Sumber data primer seperti pada kegiatan observasi dan wawancara langsung terhadap guru kelas dan peserta didik di SDN 02 Banjaran Jepara selama pelaksanaan pembelajaran di. Sedangkan data sekunder yang diperoleh peneliti adalah berupa dokumentasi yang ada di sekolah. Analisis data yang digunakan mengacu pada tiga alur kegiatan yang meliputi reduksi data, penyajian data, dan penarikan kesimpulan atau verifikasi. (Milles \& Huberman dalam Moleong, 2004).

1) Reduksi data yang dilakuka dengan data yang dianggap penting dan sesuai dengan tema agar tetap fokus dalam analisis penelitian. Dalam penelitian ini, dapat dilakukan kegiatan reduksi data yang diperoleh dari hasil wawancara, observasi, dan dokumentasi mengenai pengelolaan kelas di SDN 02 Banjaran, 2) Penyajian data dalam bentuk teks narasi dan tabel, 3) Penarikan kesimpulan dan verifikasi dengan tujuan menghasilkan suatu kesimpulan yang jelas, dapat berupa hubungan interaktif, hipotesis maupun teori baru yang belum ada sebelumnya. 


\section{HASIL DAN PEMBAHASAN}

Kegiatan pengelolaan kelas pada peserta didik di SDN 02 Banjaran dilakukan melalui observasi, wawancara, dan dokumentasi. Observasi dilakukan langsung di SDN 02 Banjaran dengan mengamati kegiatan pengelolaan kelas yang dilakukan guru selama proses pembelajaran. Kegiatan lain yang dilakukan adalah wawancara terhadap guru dan peserta didik dengan mengacu pembelajaran sehari-hari. Tujuan kegiatan wawancara adalah untuk mendapatkan infomasi riil terkait pelaksanaan pengelolaan kelas di SDN 02 Banjaran Jepara.

Teknik dokumentasi digunakan untuk mendapatkan bukti fisik selama kegiatan penelitian. Hasil deskripsi pengelolan kelas dalam kegiatan penelitian sebagai berikut:

\section{A. Prinsip-prinsip Manajemen}

1. Hangat dan antusias Kegiatan observasi dilapangan menunjukkan bahwa guru memiliki sikap hangat dan antusias sehingga peserta didik senang dalam mengikuti kegiatan belajar di kelas. Dalam konteks pengelolaan kelas, sikap penuh kegembiraan dan penuh kasih sayang kepada peserta didik sangat penting bagi seorang guru. Guru yang memiliki kepedulian dan kasih sayang akan menghormati peserta didiknya dan berusaha meningkatkan kehormatan peserta didiknya (Savage dalam Jacobsen, 2009: 41).

Melalui observasi dan wawancara hasil penelitian ini memberi kesimpulan bahwa guru sudah melaksankan prinsip hangat dan antusias. Untuk ikatan emosional guru dengan peserta didik sudah tergolong cukup baik. Namun, variasi pembelajaaran yang dilakukan guru relatif monoton. Hal ini dikarenakan kondisi lingkungan eksternal yang mempengaruhi kondisi peserta didik. Hasil ini sejalan dengan Penelitian dari Aliyyah, R. R (2016) yang menjelaskan bahwa pengorganisasian kelas menjadi kunci terciptanya keberhasilan tujuan pembelajaran yang menyenangkan

2. Tantangan

Kemampuan guru untuk memberikan tantangan kepada peserta didiknya dapat meningkatkan semangat belajar mereka sehingga hal itu dapat mengurangi kemungkinan munculnya perilaku yang menyimpang. Pada hasil observasi dan wawancara tertrsuktur, ditemukan bahwa guru telah memberikan tantangan dalam proses pembelajaran ketika mengajar tema 4 Globalisasi di kelas VI. Untuk kedepan diharapkan guru SDN 02 Banjaran lebih mengintensifkan tantangan yang positif terhadap peserta didik dalam menyelsaikan tugas individu maupun kelompok.

3. Bervariasi

Kegiatan belajar mengajar di kelas dan variasi gaya mengajar guru sangatlah dibutuhkan karena dapat menghindari kejenuhan dan kebosanan. Variasi gaya mengajar angat diperlukan guru, seperti variasi intonasi suara, gerak 
anggota badan, mimik wajah, posisi dalam mengajar di kelas, serta dalam hal penggunaan metode dan media pengajaran. Hasil pengamatan menunjukkan bahwa guru belum efektif dalam melakukan variasi pembejaran. Kondisi ini dibuktikan dengan intonasi suara yang masih pelan dan guru masih fokus menjelaskan materi di depan kelas dengan minimnya interaksi terhadap peserta didik yang berada pada tempat duduk yang paling belakang.

4. Keluwesan

Keluwesan dalam konteks pengelolaan manajemen kelas merupakan keluwesan perilaku guru untuk mengubah metode mengajar sesuai dengan kebutuhan peserta didik dan kondisi kelas untuk mencegah kemungkinan munculnya gangguan belajar pada peserta didik serta untuk menciptakan iklim belajar mengajar yang kondusif dan efektif. Pada kegiatan observasi ditemukan bahwa guru ketika mengajar sudah sesuai dengan kondisi dan situasi peserta didik yaitu guru sering menyelami kondisi fisik dan psikis dari peserta didik, namun pembelajaaran sedikit terhambat karena faktor peserta didik kelelahan akibat habis olahraga.

5. Penekanan pada hal-hal yang positif

Penekanan pada hal-hal yang positif yaitu penekanan yang dilakukan guru terhadap perilaku peserta didik yang positif. Guru telah melaksanakan penekanan hal-hal positif dengan memberikan penguatan positif dalam proses pembelajaran.

6. Penanaman disiplin diri

Tujuan akhir dari kegiatan pengelolaan manajemen kelas adalah menjadikan peserta didik dapat mengembangkan disiplin pada diri sendiri sehingga tercipta iklim belajar yang kondusif di dalam kelas. Itulah sebabnya guru diharapkan dapat memotivasi peserta didiknya untuk melaksanakan disiplin dan menjadi teladan dalam pengendalian diri serta melaksanakan tanggung jawab. Guru harus bisa menjadi model bagi peserta didik dengan memberikan contoh perilaku yang positif, baik di kelas, di sekolah, maupun di lingkungan masyarakat. Pada kondisi ini, guru sudah menanamkan disiplin diri, guru datang ke kelas tepat waktu, berpakaian sopan, tidak memakai perhiasan yang berlebihan, berbicara dengan bahasa yang santun.

\section{B. Merancang Lingkungan Fisik Kelas}

Berdasarkan hasil penelitian, sebagian guru sudah memperhatikan gaya penyusunan tempat duduk di tiap kelas, misalnya dengan mengubah tempat duduk peserta didik menjadi huruf $U$, leather L, dua meja dijadikan satu dan kursi mengelilingi meja, saling berhadapan, dan berderet ke belakang sesuai 
dengan materi yang akan disampaikan.

Pada kondisi dilapangan ditemukan bahwa gaya penyusunan tempat duduk saling berhadapan, dimana peserta didik duduk menghadap peserta didik yang lain. Hal ini sejalan dengan pendapat Renne (John W. Santrock, 2009: 261), gaya berhadap-hadapan di mana peserta didik menghadap satu sama lain. Gaya berderet ke belakang atau biasa disebut dengan gaya tradisional di mana semua peserta didik menghadap guru. Secara umum gaya penyusunan tempat duduk ini digunakan ketika guru hanya menyampaikan materi dengan menggunakan metode ceramah.

C. Menciptakan Iklim yang Positif untuk Pembelajaran

Gaya pengelolaan manajemen kelas guru di SDN 02 Banjaran Jepara ada yang menggunakan gaya otoriter, permisif, dan demokrasi. Namun, ternyata dari hasil penelitian diperoleh bahwa guru lebih umum menggunakan gaya pengelolaan manajemen kelas demokratis. Hal itu dikarenakan karena guru memberikan kesempatan pada peserta didik untuk mengeluarkan pendapat dan melibatkan peserta didik dalam aktivitas pembelajaran.

Hasil wawancara ditemukan bahwa guru dalam menciptakan iklim yang positif dengan mengacu pada kegiatan diskusi yang dilakukan secara berkelompok dalam membahasa suatu topik pembelajaran. Hal ini dapat membuat peserta didik mengeksplore pengetahuan dan keterampilan yang mereka miliki.

\section{Menerapkan Peraturan}

Berdasarkan hasil penelitian, setiap guru SDN 02 Banjaran agar aturan yang dibuat dapat disepakati dan dipatuhi peserta didik melalui berbagai cara, yaitu memberikan hukuman atau hadiah yang masuk akal, menggunakan bahasa yang sopan dan halus, membuat peraturan yang jelas dan mudah dipahami, peraturan yang dibuat berlaku untuk peserta didik maupun guru, serta banyak mengajak peserta didik untuk berkomunikasi. Hal tersebut sesuai dengan pendapat Asep Jihad dan Suyanto (2013: 97) yang memberikan beberapa saran agar aturan dapat disepakati peserta didik secara bersama, yaitu dengan membuat aturan seminimal dan sejelas mungkin, memberikan hadiah atau hukuman yang masuk akal

\section{E. Mengajak Peserta didik Saling} Bekerja Sama

1. Mengembangkan Hubungan

Positif dengan Peserta didik

Hasil penelitian diperoleh informasi bahwa cara mengembangkan hubungan positif pada peserta didik, yaitu melayani peserta didik dengan sebaik mungkin, memberikan perhatian pada peserta didik, dan interaksi guru dan peserta didik dapat menjadi teman, dan mengajak peserta didik bermain sambil belajar.

2. Saling Berbagi dan Memikul Tanggung Jawab

Berdasarkan hasil penelitian, cara yang dilakukan guru untuk mengajarkan peserta didik saling berbagi, yaitu dengan memberikan 
arahan positif pada peserta didik, melalui pemberian nasehat dan motivasi. Selain itu, tiap guru juga mengajarkan peserta didik untuk mengemban tanggung jawab. Hal ini sesui dengan peelitian Ummu Hany Almasitoh (2012) untuk mengajak siswa saling berbagi dan bertanggung jawab diantaranya, yaitu jangan menerima alasan siswa melakukan kesalahan dan memberi waktu siswa untuk mau menerima tanggung jawab.

3. Menghargai Perilaku yang Pantas

Berdasarkan hasil penelitian, guru sudah memberikan nasehat dan sanksi pada peserta didik yang berperilaku kurang baik. Pemberian nasehat dan sanksi memiliki konsekuensi penting yang harus diperhatikan guru dengan tujuan mendorong timbulnya perilaku yang patuh bagi peserta didik yang berperilaku kurang baik. Untuk peserta didik berperilaku baik, penghargaan paling efektif, yaitu dengan pujian (John W. Santrock, 2009: 270).

\section{F. Menciptakan Iklim Psikologis yang Efektif}

Menciptakan iklim psikologis yang efektif pada peserta didik merupakan hal penting yang dapat membuat peserta didik menjadi nyaman mengikuti kegiatan pembelajaran sehingga tujuan pembelajaran yang telah direncanakan dapat tercapai.

Hasil penelitian ditemuka bahwa cara setiap guru berbeda-beda dalam hal menciptakan iklim psikologis yang efektif pada peserta didik, yaitu membuat kegiatan pembelajaran menjadi menyenangkan, mengatur tempat duduk sedemikian rupa dan rapi, dan menciptakan suasana kelas yang menghargai dan saling berbagi. Selain itu, tidak memarahi peserta didik tanpa alasan yang jelas, menyampaikan pesan kepada peserta didik tentang nilai moral dari pembelajaran di sekolah.

\section{G. Menjadi Komunikator yang Baik}

1. Keterampilan Berbicara

Hasil penelitian ditemuakan bahwa guru sudah baik dalam menerapkan ketrampilan berbicara dalam pengajaran. Hal ini dibuktikan ketika guru berkomunikasi dengan peserta didik secara intensif.

2. Keterampilan Mendengarkan

Mengelola kelas secara efektif akan menjadi lebih mudah apabila guru dan siwa mempunyai keterampilan baik. Hal ini sejalan dengan Alrochmah, N. (2013) menjelaskan bahwa peserta didik yang tidak pandai dalam mendegarkan, maka akan berakibat sulit memahami materi pembelajran dan kemungkinan akan mengalami sebuah kegagalan.

Hasil penelitian didapat
bahwa ditemukannya cara
membaca bergilir dengan
menunjuk peserta didik secara
acak dan melemparkan pertanyaan
tiba-tiba tentang materi yang telah
disampaikan. Dengan cara di atas,
keterampilan mendengarkan
peserta didik dapat meningkat dan


lebih fokus dalam mengikuti kegiatan pembelajaran.

3. Komunikasi Nonverbal

Komunikasi nonverbal hanyalah berupa gerakan anggota tubuh untuk mempertegas maksud yang disampaikan. Komunikasi nonverbal dapat terlihat ketika proses berbaur dengan lawan bicara, misalnya gerakan, ekspresi wajah, gerakan mata, ataupun karakteristik suara. Untuk menjadi seorang komunikator yang baik dapat melalui meningkatkan keterampilan berbicara, keterampilan mendengarkan, komunikasi nonverbal (Puspitaningrum, E, 2017).

Komunikasi non verbal yang ditemukan dalam penelitian ini, meliputi penggunaan komunikasi nonverbal ketika terdapat peserta didik yang berani maju dan berhasil menjawab pertanyaan, guru memberikan tepuk tangan dan acungan jempol. Selain itu, ketika guru meminta peserta didik untuk diam dengan menggunakan ekspresi wajah dan gerakan mata dan membelai rambut peserta didik dengan tujuan menunjukkan rasa sayang pada peserta didik.

\section{SIMPULAN}

Berdasarkan hasil penelitian mengenai pengelolaan kelas terhadap proses pembelajaran di SDN 02 Banjaran, dapat disimpulkan sebagai berikut:

1. Secara keseluruhan proses pengelolaan kelas oleh guru dalam mengajar berjalan dengan cukup baik.

2. Rata-rata guru mampu menerapkan prinsip-prinsip manajemen kelas seperti hangat dan antusias, tantangan, bervariasi, keluesan, penekanan pada hal-hal yang positif, dan penanaman disiplin diri. Dari keenam prinsip tersebut sudah dilaksankan dengan baik, namun untuk prinsip melakukan variasi dalam penggunaan metode dan media pembelajaran, guru masih sangat kurang efektif, selain itu terdapat kendala dalam hal keluwesan guru dalam mengubah metode belajar sesuai dengan kebutuhan peserta didik.

3. Guru mampu merancang lingkungan fisik kelas seperti penyusunan gaya tiap kelas, mampu menciptakan iklim positif dalam pembelajaran namun masih terdapat kenadala dalam hal penggunaan metode dan media. Selain itu cara setiap guru berbeda-beda dalam hal menciptakan iklim psikologis peserta didik yang efektif.

\section{DAFTAR PUSTAKA}

Aliyyah, R. R., \& Abdurakhman, O. (2016). Pengelolaan Kelas Rendah di SD Amaliah Ciawi Bogor. Jurnal Sosial Humaniora, 7(2), 81-95.

Almasitoh, U. H. (2012). Menciptakan lingkungan yang positif untuk pembelajaran. MAGISTRA, 24(79), 87.

Alrochmah, N. (2013). Penerapan Metode Hypnoteaching Berbasis Pemecahan Masalah dalam Pembelajaran Menyimak Informasi (Doctoral dissertation, Universitas Pendidikan Indonesia).

Asep Jihad dan Suyanto. (2013). Menjadi Guru Professional: Strategi Meningkatkan Kualifikasi dan Kualitas Guru di Era Global. Jakarta: Esensi 
Djamarah SB. (2006). Guru dan anak didikdalam interaksi edukatif. Rineka Cipta : Jakarta.

Danim, Sudarwan. \& Yunan, Danim. (2010). Administrasi Sekolah dan Pengelolaan manajemen kelas. Bandung: Pustaka Setia.

Jacobsen, Eggen dan Kauchak. (2009). Methods for Teaching: Metodemetode Pengajaran Meningkatkan Belajar Peserta didik TKSMA. Terjemahan Fawaid dan Anam. 2009. Yogyakarta: Pustaka Pelajar

Mudasir, 2011, Manajemen kelas. Pekanbaru Riau: Zanafa Publishing.

Moleong, L. J., \& Edisi, P. R. R. B. (2004). Metodelogi penelitian. Bandung: Penerbit Remaja Rosdakarya.

Puspitaningrum, E. (2017). Kemampuan Guru dalam Pengelolaan Kelas di SD Negeri Minomartani 2. BASIC EDUCATION, 6(1), 28-39.

Santrock, John W. (2009). Psikologi Pendidikan Edisi 3. Penerjemah: Diana Angelica. Jakarta: Salemba Humanika.

Syamsuwir, S. (2019). GURU SEBAGAI MANAJER. Indonesian Journal of Islamic Educational Management, 1(1), 37-43.

Wibowo, 2013. Manajemen Perubahan. Jakarta: Raja Granfindo Persada 